\title{
Breast cancer awareness and practice of breast self examination among women in Adiabo community in Odukpani local government area of Cross River State, Nigeria
}

\author{
Ojong Idang Neji * Esienumoh Ekpoanwan Esienumoh, Uka Victoria Kalu, Edet Olaide Bamidele \\ Department of Nursing Science, University of Calabar, Cross River State, Nigeria
}

Received: September 8, 2015

DOI: $10.5430 / \mathrm{cns} . v 4 \mathrm{n} 1 \mathrm{p} 50$
Accepted: November 16, 2015 Online Published: December 8, 2015

URL: http://dx.doi.org/10.5430/cns.v4n1p50

\begin{abstract}
Introduction: Breast cancer is a malignant tumor that develops in the cell of the breast and continues to remain the most lethal malignancy in women across the world. The purpose of the study was to investigate breast cancer awareness and practice of breast self examination among women in Adiabo Community in Odukpani Local Government Area.

Methods: The study adopted a cross sectional design. Multistage random sampling technique was used to select 345 women used in the study. Questionnaire was instrument for data collection and the chi-square test analysis was used to test the relationship between variables.

Results: One hundred and sixty (46.4\%) respondents were aware of breast cancer and 155(45\%) respondents were aware of breast self examination. One hundred and fifty (43.5\%) respondents practised breast self examination. Findings also revealed a positive significant association between breast cancer awareness and practice of breast self examination.

Conclusions: The study concluded that there was low awareness of breast cancer and inadequate practice of breast self examination by respondents. It was recommended that emphasis should be placed on importance of breast self examination as a key factor in the early detection of breast cancer among women in rural communities.
\end{abstract}

Key Words: Breast cancer, Breast self-examination, Awareness and practice

\section{INTRODUCTION}

Breast cancer is the commonest and the worst malignant growth and the leading cause of death from cancer in women. ${ }^{[1]}$ It causes death three times more frequently than cancer of the cervix and affects women of age range 15-50 years. ${ }^{[2]}$ Globally, the prevalence of breast cancer is estimated to be over 1 million women per year and the death toll from it is as high as 500,000 deaths annually. ${ }^{[3]}$ Breast cancer is the number one cause of cancer death among Nigerian women, peak age of incidence is $30-40$ years, a decade earlier than the Caucasian. The 5 years survival rate of breast cancer in Nigeria is less than $10 \%$ compared with more than $70 \%$ in Western European and North America. ${ }^{[4]}$

In Nigeria, cancer is becoming a major health problem overtaking diseases like HIV/AIDs. Also 250,000 cases of cancer related deaths are recorded annually. ${ }^{[5]}$ Lack of knowledge

\footnotetext{
${ }^{*}$ Correspondence: Ojong Idang Neji; Email: Idangojong@yahoo.com; Address: Department of Nursing Science, College of Medical Sciences, University of Calabar, P. M. B. 1115, Calabar, Cross River State, Nigeria.
} 
and resources exacerbates the situation and hinders the ability to adequately respond to the rising incidence. ${ }^{[6]}$ The lack of effective screening and treatment strategies are also a major contributing factor to the increasing rates of this cancer in Nigeria and other developing countries. ${ }^{[7]}$ Late presentation is the hallmark of cancers in Nigerian women. Over $80 \%$ of women will present with late stage of cancer at which time little or no benefits can be derived from the therapy. ${ }^{[8]}$

In an environment where late presentation is predominant and where most breast cancers were detected incidentally by women themselves, there is need for awareness of breast cancer and its early detection measures. Recommended preventive techniques to reduce breast cancer mortality and morbidity include breast self examination (BSE), Clinical breast examination and mammography. ${ }^{[9]}$ Early diagnosis has a positive effect on the prognosis as well as limits the development of complication and disability. ${ }^{[10]}$

On awareness of breast cancer and breast self examination in Nigeria among 428 secondary school teachers in Enugu Metropolis, ${ }^{[11]}$ the results showed that 398(93.0\%) respondents knew that breast cancer could be detected early, while $389(90.9 \%)$ identified breast self examination as a screening test. Regular practice of BSE was high 300(70.1\%) among secondary school teachers. The study also revealed that educational attainment and higher socio-economic status correlated positively with BSE performance, as did age. The younger teachers were more aware than the older ones. The younger teachers who were more educated were more knowledgeable about breast cancer and BSE. The findings were inconsistent with ours which was conducted in a rural setting with majority of the respondents having non formal education and were not privileged to have available information on breast cancer and BSE.

Also in a cross sectional study on knowledge and practice of BSE among undergraduate students in Ahmadu Bello University Zaria, ${ }^{[12]}$ the result revealed that out of 221 respondents, 190(86.9\%) have heard of BSE, only 50(26.3\%) of the respondents performed BSE monthly. The study also revealed that younger women who were more educated were knowledgeable about BSE but the practice of BSE was low among them which the students attributed to as being too busy with academics as the most important reasons.

Despite the growing campaigns on breast cancer awareness in Nigeria, the practice of BSE continues to vary widely among women. Rural women formed group that are often neglected in breast cancer research. Available literature revealed that rural women have poor practice of BSE, both in techniques and timing, often in the light of a poor knowledge of breast cancer. ${ }^{[8]}$ In most Nigerian villages, access to health care services especially comprehensive diagnostic service is very low and often unavailable and there is need for an interventional study to enhance the awareness of breast cancer and its early detection measures among the rural population to influence early detection of breast cancer and subsequently reduce morbidity and mortality. ${ }^{[10]}$ Also is a study on awareness, attitude and practice of rural women regarding breast cancer in South East Nigeria, ${ }^{[13]}$ using 1,600 rural women aged 20 to 60 years. Results showed that only 931(58.2\%) of them have heard of breast cancer. Of these, 263(28.2\%) perceived it as being medical cause, 199(21.4\%) as spiritual, 194(20.8\%) as hereditary. This shows a misconception about breast cancer, so the study concluded that there is critical need for more and sustained awareness on breast cancer to dispel this misconception.

In another study on attitude to, knowledge and practice of BSE in Port Harcourt, ${ }^{[14]}$ the women though were aware of BSE and its usefulness never practiced it. Out of the 200 women used in the study, $100(50 \%)$ of them have heard of BSE but $60(30 \%)$ practice BSE occasionally, while 40(20\%) did not practice it at all. An increased awareness on regular self breast examination as a means of detecting breast cancer would most likely result in a higher proportion of women practicing it, ${ }^{[15]}$ if there is increased awareness and improvement in the capacity of women to understand themselves it will enable them seek medical attention early enough. ${ }^{[16]}$

Based on the fact that greater percentage of Nigerian women die because of late presentation and that awareness on BSE increases the possibility of early presentation and consequently reduces mortality, ${ }^{[17]}$ this study is designed to determine the breast cancer awareness and practice of BSE among women in rural community in Cross River State who constitute the majority of women at risk both for the disease and late presentation.

\subsection{The purpose of the study}

The study was to investigate breast cancer awareness and practice of breast self-examination among women in Adiabo Community in Odukpani Local Government Area.

\subsection{Research questions}

(1) How aware are the women of Adiabo Community in Odukpani Local Government area of breast cancer?

(2) How aware are the women of Adiabo Community in Odukpani Local Government Area of breast self examination?

(3) How do women in Adiabo Community in Odukpani Local Government Area practised breast self examination? 


\subsection{Research hypothesis}

There is no significant association between breast cancer awareness and practice of BSE among women in Odukpani Local Government Area.

\subsection{Significance of the study}

Data generated in this study revealed awareness of breast cancer and practice of breast self examination among women in rural setting. Finding is expected to provide information to health care providers that will shape their education and awareness programmes on BSE and breast cancer in this setting. Consequently, this will reduce late detection and thus reduction in mortality rate due to late presentation.

The information obtained from this study may be of help to other researchers interested in working in this field as it will serve as a reference material for further research.

\section{Methods}

\subsection{Study design}

A cross sectional descriptive study was adopted to find out breast cancer awareness and practice of breast selfexamination among women in Adiabo Community in Odukpani Local Government Area of Cross River State, Nigeria.

\subsection{Study setting}

This study was conducted in Adiabo Community in Odukpani Local Government Area of Cross River State, Nigeria. Seven villages made up the community namely: Ikot Ukpa, Ikot Mbo, Okurikang, Akani-obio, Ibonda, Mkpara Otop and Ukpaha Ata. It is bounded in the North by Okoyong, South by Ikot Ekpo, West by Creek town and East by Akim-Akim. It has seven polling booths and one political ward. It has three ${ }^{[3]}$ health centres and one health post, there are seven primary schools and two secondary schools in the community. Two major markets are located in Adiabo where people by and sell on the four market days. The women in Adiabo are mostly farmers and traders.

\subsection{Study population}

The target population was all women living in Adiabo Community which was 2,500. This number was obtained from women's village meeting registers of those residing in the seven villages namely: Ikot Ukpa, Ikot Mbo, Okurikang, Akani-obio, Ibonda, Mkpara Otop and Ukpaha Ata.

\subsection{Sample size}

A sample size of 345 women from Adiabo Community in Odukpani Local Government Area of Cross River State was used for the study. This was calculated using Taro Yamane's formula: $\mathrm{N} / 1+\mathrm{N}(\mathrm{e})^{2}$. Selection of respondents was based on the inclusion criteria which were willingness to participate, present at time of the study and physical fitness of the respondents.

\subsection{Sampling technique}

The multi stage random sampling technique was used. The first stage involved random selection of five villages from the seven villages. To reach the respondents in each village, simple random sampling technique was used to locate 69 houses each from the five villages. Thereafter five women were conveniently selected from each of the 69 houses totaling 345 respondents. The women in each house that met the inclusion criteria were selected based on their present, physical fitness and willingness to participate.

\subsection{Research instrument}

The data were obtained through a questionnaire which served as an interview schedule developed by the researcher titled breast cancer awareness and practice of BSE with 20 items divided into two sections. Section A which had 5 items sought information on socio-demographic data of respondents while section B which had 15 items sought respondents information on breast cancer awareness, BSE awareness and practice of BSE. Positive comments by psychometric experts were suggestive of the face validity and reliability test was done using a test-retest which yielded a reliability coefficient of 0.80 .

\subsection{Data collection procedure}

Data for the study were collected using a self developed breast cancer awareness and BSE practice questionnaire which served as an interview guide. The questionnaires were administered to all the 345 respondents by the four researchers, same was interpreted in local language (Efik) to those who were non-literate, and all questionnaires were retrieved from the respondents. The researchers used five weeks for collection of data by dedicating one week to each village.

\subsection{Human rights and research ethics}

A written permission to conduct the study was sought from the supervisory councillor for health in Odukpani Local Government Area and from the authority of Chiefs in Odukpani and Adiabo Community. Thereafter a written and informed consents were obtained from the respondents while their opinions were respected in the study. Researchers explained the purpose of the study to the women which was to investigate breast cancer awareness and practice of breast self examination among women in Adiabo Community in Odukpani Local Government Area. The respondents were assured of their confidentiality and participation was voluntary. 


\subsection{Data Analysis}

Data were analyzed using SPSS 21 window. Frequency distribution and percentages were used for the descriptive data. The data was thus considered continuous with interval level of measurement assured, since the instrument was validated. To test the null hypothesis, chi-square test analysis was used to test the association between knowledge of breast cancer and practice of BSE. The hypothesis was tested at 0.05 level of significance.

\section{RESUlts}

Demographic data of respondents were reported in Table 1. The participants $162(47 \%)$ were mostly between age 36-45 years. Education wise, majority of the respondents $153(44.3 \%)$ had no formal education, followed by primary education $102(29.6 \%)$, secondary $60(17.4 \%)$ while tertiary was $30(8.7 \%)$. The respondents' occupation were mainly trading 160(46.4\%) and farming 115(33.3\%). The respondents were mostly married 200(58\%), and the highest annual income was between the range NGN 50,000 - NGN 100,000 while the least was NGN 400,000 - NGN 500,000.

Participants awareness on breast cancer was very low as 185(53.6\%) have not heard of breast cancer (see Table 2). Only $50(14.5 \%)$ indicated that breast cancer is abnormal growth in the breast while 170(49.3\%) indicated that breast cancer is caused by ancestral power. Also 160(46.4\%) respondents have seen cases of breast cancer and 150(43.5\%) indicated BSE, 100(29\%) mentioned clinical breast examination by health workers and 80(23.2\%) indicated mammography as ways of detecting breast cancer early.

Table 1. Socio-demographic data of the respondents $n=345$

\begin{tabular}{|c|c|c|}
\hline Items & Frequency & Percentage \% \\
\hline \multicolumn{3}{|l|}{ Age in years } \\
\hline $15-35$ years & 50 & $14.5 \%$ \\
\hline $36-45$ years & 162 & $47 \%$ \\
\hline $46-60$ years & 195 & $27.5 \%$ \\
\hline 60 and above & 38 & $11 \%$ \\
\hline \multicolumn{3}{|l|}{ Educational attainment } \\
\hline Non-formal & 153 & $44.3 \%$ \\
\hline Primary & 102 & $29.6 \%$ \\
\hline Secondary & 60 & $17.4 \%$ \\
\hline Tertiary & 30 & $8.7 \%$ \\
\hline \multicolumn{3}{|l|}{ Occupation } \\
\hline Civil Servant & 50 & $14.5 \%$ \\
\hline Trading & 160 & $46.4 \%$ \\
\hline Farming & 115 & $33.3 \%$ \\
\hline House wife & 20 & $5.8 \%$ \\
\hline \multicolumn{3}{|l|}{ Annual Income } \\
\hline$\$ 50,000-\$ 100,000$ & 120 & $34.8 \%$ \\
\hline$\# 101,000-\# 300,000$ & 100 & $29 \%$ \\
\hline$\$ 301,000-\$ 400,000$ & 80 & $23.2 \%$ \\
\hline$\$ 401,000-\$ 500,000$ & 45 & $13 \%$ \\
\hline \multicolumn{3}{|l|}{ Marital Status } \\
\hline Single & 65 & $18.8 \%$ \\
\hline Married & 200 & $58 \%$ \\
\hline Divorced & 50 & $14.5 \%$ \\
\hline Widow & 30 & $8.7 \%$ \\
\hline
\end{tabular}

Table 3 revealed that few of the respondents $155(45 \%)$ have heard of BSE. One hundred and Ninety-two (55.7\%) indicated that BSE is to detect lump in the breast, 39(11.3\%) said it is assessment done by health worker to detect lump, while $30(8.7 \%)$ indicated that it is using fingers around the breast to detect lump. On abnormalities to check for during BSE, $20(5.8 \%)$ said breast lump, 30(8.8\%) mentioned swelling, $25(7.3 \%)$ mentioned discharges, while 32(9.3\%) mentioned unusual pains.

Published by Sciedu Press 
Table 2. Awareness of breast cancer among women in Adiabo Community in Odukpani Local Government Area $n=345$

\begin{tabular}{|c|c|c|c|c|c|}
\hline $\mathbf{S} / \mathbf{N}$ & Questions & Options & Yes (\%) & No (\%) & Don't know (\%) \\
\hline 1. & Have you heard of breast cancer & & $160(46.4 \%)$ & $185(53.6 \%)$ & - \\
\hline \multirow{4}{*}{2.} & \multirow{4}{*}{ What do you understand by breast cancer } & Abnormal growth in the breast & $50(14.5 \%)$ & $100(29 \%)$ & $195(56.5 \%)$ \\
\hline & & An illness that is caused by ancestral power & $170(49.3 \%)$ & $20(5.8 \%)$ & $155(44.9 \%)$ \\
\hline & & A lump in the breast & $160(46.4 \%)$ & $50(14.5 \%)$ & 135(39.1\%) \\
\hline & & A discharge in the breast & 102(29.6\%) & $80(23.2 \%)$ & $163(47.2 \%)$ \\
\hline 3. & Have you seen anybody with breast cancer & & $160(46.4 \%)$ & $185(53.6 \%)$ & - \\
\hline \multirow{4}{*}{4.} & & Breast self-examination & $150(43.5 \%)$ & $10(2.9 \%)$ & $185(53.6 \%)$ \\
\hline & Which of the following do you think are & Clinical breast examination by health worker & $100(29 \%)$ & $14(4 \%)$ & $231(67 \%)$ \\
\hline & ways of detecting breast cancer? & Mammography & $80(23.2 \%)$ & $16(4.6 \%)$ & $249(72.2 \%)$ \\
\hline & & Ultrasound & $70(20.3 \%)$ & $20(5.8 \%)$ & 255(73.9\%) \\
\hline
\end{tabular}

Table 5 showed an association between awareness of breast cancer and breast self examination. The practice of breast self examination affects the awareness of breast cancer. It showed that there is a relationship between inadequate practices of breast self examination and low awareness of breast cancer.

Table 3. Awareness of Breast self examination among women in Adiabo community in Odukpani Local Government Area $n=345$

\begin{tabular}{|c|c|c|c|c|c|}
\hline $\mathbf{S} / \mathbf{N}$ & Questions & Options & Yes (\%) & No (\%) & Don't know (\%) \\
\hline 1. & $\begin{array}{l}\text { Have you heard of breast } \\
\text { self-examination }\end{array}$ & & $155(45 \%)$ & $117(34 \%)$ & $73(21 \%)$ \\
\hline \multirow{3}{*}{2.} & \multirow{3}{*}{$\begin{array}{l}\text { What is breast } \\
\text { self-examination? }\end{array}$} & BSE is to detect lump in the breast & $192(55.7 \%)$ & $133(38.5 \%)$ & $20(5.8 \%)$ \\
\hline & & Assessment done by nurses/doctors to check lump & $39(11.3 \%)$ & $120(34.8 \%)$ & $186(53.9 \%)$ \\
\hline & & BSE is using fingers around your breast to palpated for lump & $30(8.7 \%)$ & $20(5.8 \%)$ & $295(85.3 \%)$ \\
\hline \multirow{3}{*}{4.} & \multirow{3}{*}{$\begin{array}{l}\text { Which of these } \\
\text { abnormalities should be } \\
\text { checked for during BSE? }\end{array}$} & Breast lump & $20(5.8 \%)$ & $145(42 \%)$ & $180(52.2 \%)$ \\
\hline & & Discharge & $25(2.3 \%)$ & $121(35 \%)$ & $199(57.7 \%)$ \\
\hline & & Unusual pains & $32(9.3 \%)$ & 135(39.1\%) & 178(51.6\%) \\
\hline
\end{tabular}

The result in Table 6 showed a significant positive association between awareness of breast cancer and practice of breast self examination. The expected count of less than 5 is less than the tabulated count of 7.51 with 4 degrees of freedom.

Table 4. Practice of breast self examination among women to Adiabo Community in Odukpani Local Government Area $n=$ 345

\begin{tabular}{|c|c|c|c|}
\hline S/No & Variables & Options & Total (\%) \\
\hline \multirow{2}{*}{1.} & \multirow{2}{*}{ Have you ever performed breast self-examination? } & Yes & $150(43.5 \%)$ \\
\hline & & No & $195(56.5 \%)$ \\
\hline \multirow{4}{*}{2.} & \multirow{4}{*}{ If yes how often do you perform BSE $n=150$} & Daily & $5(3.3 \%)$ \\
\hline & & Weekly & $50(33.3 \%)$ \\
\hline & & Monthly & $70(46.7 \%)$ \\
\hline & & Yearly & $25(16.7 \%)$ \\
\hline \multirow{4}{*}{3.} & \multirow{4}{*}{ What time do you perform BSE? } & $1^{\text {st }}$ day of menses & $30(20 \%)$ \\
\hline & & $2^{\text {nd }}$ day of menses & $40(26.7 \%)$ \\
\hline & & Last day of menses & $50(33.3 \%)$ \\
\hline & & During ovulation & $30(20 \%)$ \\
\hline
\end{tabular}

\section{Discussion}

The Socio demographic data revealed that majority of the respondents were married and had non formal and primary education respectively. The participants were mostly traders and farmers belonging to low social class and were between age range 36-45. The result is quite different from the study conducted among teachers in Enugu Metropolis ${ }^{[11]}$ which re- ported a positive correlation between higher socio-economic status with BSE performance and younger women more aware than the older ones. In our study we concluded the reason for low awareness on BSE as due to low level of education with economic challenges and rural geographical location which hinders exposure to information on breast cancer and BSE. 
Table 5. Cross calculation between breast cancer awareness and practice of self examination $n=345$

\begin{tabular}{lllll}
\hline \multirow{2}{*}{ Awareness of breast cancer } & \multicolumn{4}{c}{ Practice of breast self-examination } \\
\cline { 2 - 4 } & Inadequate (\%) & Moderately adequate (\%) & Highly adequate (\%) & Total (\%) \\
\hline Low & $160(91.4 \%)$ & $10(5.7 \%)$ & $5(2.9 \%)$ & $175(100 \%)$ \\
Moderate & $60(51.3 \%)$ & $30(25.6 \%)$ & $27(23.1 \%)$ & $117(100 \%)$ \\
High & $18(34.0 \%)$ & $5(9.4 \%)$ & $30(56.6 \%)$ & $53(100 \%)$ \\
Total & $238(69.0 \%)$ & $45(13.0 \%)$ & $62(18.0 \%)$ & $345(100 \%)$ \\
\hline
\end{tabular}

Results of the findings from data collected on awareness of breast cancer revealed that respondents' awareness on breast cancer was low. This is indicated by the fact that majority of the women neither knew the meaning of breast cancer nor signs and symptoms or ways of detecting breast cancer because of their low level of educational attainment and geo- graphical location. This leads to confirm the assertion ${ }^{[10]}$ that there is need for an interventional study to enhance the awareness of breast cancer and its early detection measures among the rural population to influence early detection of breast cancer and subsequently reduce morbidity and mortality.

Table 6. Chi-square tests (cross tabulation between breast cancer awareness and practice of BSE)

\begin{tabular}{llll}
\hline & Value & df & Asymp. Sig. 2 sided \\
\hline Pearson chi-square & $154.421^{*}$ & 4 & .000 \\
Likelihood ratio linear-by-linear & 163.213 & 4 & .000 \\
Association & 125.658 & 1 & .000 \\
Number of valid cases & 345 & & \\
\hline
\end{tabular}

* O.cells (.0\%) have expected count less than 5 . The minimum expected count is 7.51 with df 4

Findings from this study also revealed that majority of the women had low awareness level of breast self examination. Indeed, the result give support to the earlier result stated. Only few respondents were aware of BSE and the abnormalities to be checked for during BSE. This is however contrary to the findings of some authors ${ }^{[11,12]}$ who reported high awareness of BSE. In the above studies, the respondents were secondary school teachers and undergraduate students that have had a high level of education and located in urban region and were exposed to abundance of information available on BSE and breast cancer. While the majority of respondents used in our study, had no formal education and were rural dwellers that may not have privileged information on breast cancer awareness and practice of BSE. The difference between the two groups is that a higher level of education and urban geographical location had a positive correlation with breast cancer awareness and practice of BSE.

The findings from practice of BSE, revealed that majority of the respondents showed inadequate practice of BSE. This could be attributed to their low awareness of BSE. The result in Table 6 showed that using chi-square analysis, there is a significant positive association between respondent's awareness of breast cancer and practice of breast self examination. This shows that the practice of breast self examination is associated with the awareness of breast cancer.

\section{Conclusion}

Women in this study setting may be at risk of morbidity and mortality with regards to breast cancer. As revealed by this study, the awareness level of majority of the respondents on breast cancer and BSE were low, thus the practice of BSE was also inadequate. This shows that the practice of BSE is associated with the awareness of breast cancer. It is needful for the women to be educated on practical demonstrations of BSE to clear gray areas and improve practice. Health care providers should be more involved in the dissemination of BSE information and information passed on through the mass media should be screened for completeness as this will lead to early detection of lumps which are most likely benign. And for breast cancers detected early (Stage 1) 100\% cure is achievable.

\section{Implications for nursing practice and future research}

The findings of the study showed that a greater proportion of the women in Adiabo Community had low awareness of breast cancer and BSE. This therefore emphasized the need to continually create a forum for health workers especially community health nurses to educate women in the rural communities on breast cancer and BSE. The health workers should therefore not relent in their efforts in health educating the masses and teaching them the appropriate skills required for BSE. 


\section{REFERENCES}

[1] National Breast cancer foundation. The Daily Telegraph. 2008 August [cited 2010 April 21]. 26(1): 2-4. Available from: ww. nationalbreastcancer.org/aboutbreastcancer/bre astselfexamination

[2] World Health Organization (WHO). Breast cancer prevention and control [Internet]. 2013 May 24 [Cited 2013]. Available from: http://www.who.int/cancer/detection/breastcan cer/en/print/html

[3] World Health Organization (WHO). Screening and early detection of cancer [Internet]. 2013 April 16 [Cited 2013]. Available from: http://wwwwho.int/cancer/detection/en

[4] Oluwatosin O. Primary Health care nurses' knowledge, practice and client teaching of early detection measures of breast cancer in Ibadan. BMC Nursing. 2012; 11: 1-8.

[5] Ojong IN, Etim PE, Samson-Akpan PE, et al. Utilization of cervical cancer screening services by women of child bearing age in Uyo Metropolis, Akwa Ibom State Mary Slessor. Journal of Medicine. 2013; 12(1): 24-32.

[6] Akpo EE. Breast cancer knowledge and screening practices among Nigerian medical students. Internet Journal of Health. 2010; 11(2): 6-9.

[7] Bray FD, Ren JS, Ferlay J. Global estimates of cancer prevalence for 27 sites in the adult population in 2010. Int cancer. 2012; 4(2) 20-26.

[8] Makanguola OJ, Amoo PO, Ajibade BL, et al. Breast cancer: knowledge and practice of breast self examination among. Women in rural community of Ondo State Nigeria 10 SR. Journal or Pharmacy and Biological Science. 2003; 8(1): 321-37.
[9] Shaminan J. The role of nurses as agents for change in teaching breast self examination to healthy women in the community. WACN. 2010 Nov; 6(2): 9-12.

[10] Saladin KS. Acceptability and effectiveness of a breast health awareness programme for rural women in India. Indian Journal of med. Sc. 2010; (10): 398-420.

[11] Aniebu P. Awareness of breast cancer and breast self examination among female secondary school teachers in Enugu Metropolis. South Eastern Nigeria International Journal of Tropical Medicine. 2008; 6(1): 26-38

[12] Gwarzo U, Sabitu K, Idris S. Knowledge and practice of BSE among female undergraduate students of Ahmadu Bello University Zaria. North Western Nigeria. Annals of African Medicine. 2009; 8(1): 55-58. PMID:19763009. http://dx.doi .org/10.4103/1596-3 519.55766

[13] Onwere S, Okoro O, Chigbue B, et al. Breast self examination as a method of early detection of breast cancer. KAP among antenatal clinic attendees in South Eastern Nigeria. Pak J med Sc. 2009; 25(1): 122-125.

[14] Jebbin NJ, Adotey JM. Attitude to, knowledge and practice of breast self examination in Port Harcourt. Nigeria Journal of Medicine. 2009; 13(2): 166-170.

[15] Okobia MN, Bunker CH, Okonofua FE, et al. Knowledge, attitude and practice of Nigerian women towards breast cancer: A cross sectional study. World Journal or surgical Oncology. 2006; 21(4): 1-9.

[16] Oluwatosin O. Assessment of women's risk factors for breast cancer and predictors of the practice of BSE in two rural areas in Ibadan Nigeria. Cancer epidemiology. 2010; 34(2): 245-428.

[17] Onyebuchi C. Are cancers cases increasing in Nigeria? The national line. 2012; 2(1): 11. 